\title{
COMMODITY TRADE STABILIZATION THROUGH INTERNATIONAL AGREEMENTS
}

\author{
Hans W. Gerhard*
}

\section{INTRODUCTION}

There is no fixed list of economically possible types of commodity agreements; nor is there a fixed list of their objectives and, consequently, there are no fixed criteria of their success. In what follows, we shall limit ourselves to a consideration of multilateral intergovernmental agreements taking the form of (I) buffer stock schemes, (2) long-run purchase contracts, and (3) trade quotas. The currently operative agreements provide examples for at least some aspects of every one of these three basic forms.

As to objectives and criteria of success we shall consider only (a) price stabilization, and (b) terms of trade stabilization. ${ }^{1}$

No particular effort toward empirical identification of the various theoretical conditions will be made. Throughout, it will be assumed that factual instability is well established for the trade in those commodities for which agreements are proposed. It will not be assumed, however, that stabilization is indicated for every one case of high instability; nor that where stabilization policies are indicated, they must take the form of commodity agreements. Availability and superiority of other policies limit the list of potential cases. ${ }^{2}$ More important, a wide dispersion of either temporarily or permanently conflicting interests further reduces such a list. ${ }^{3}$ A necessary condition for commodity agreements is their negotiability. A more complete economic theory of commodity agreements would, therefore, have to aim at

- Dr.rer.pol. 1958, Tübingen University (Germany). Associate Professor of Economics, Duke University. The author gratefully acknowledges suggestions and criticism from Professors John O. Blackburn, Louis DeAlessi, and John S. McGee, all of Duke University. The responsibility for the contents of this article is, of course, his own.

${ }^{1}$ Specifically excluded from our consideration are balance of payments problems. Since the net position on current account in the balance of payments always reflects all of an economy's transactions, and, above all, the availability of credit, commodity trade stabilization is unlikely to be the most important aspect of balance of payments policy.

2 Among the most important alternative policies of international trade stabilization are ( $\mathrm{r}$ ) world-wide anticyclical measures financed through an international agency: countries "saving" on imports because they failed to maintain "normal" levels of demand directly compensate export countries for the loss of export receipts caused by importer countries' "policy decisions," i.e., by the decision not to support normal levels of demand; cf. United Nations, National and International Measures for Full Employment (1949); (2) international insurance schemes for compensation of export losses. CF. UNITED Nitzons, International Compensation for Fluctuations in Commodity Trade (ig6i).

${ }^{8}$ Apart from conflicting interests of producers and consumers in each country there is above all the possibility that international trade in general is stabilizing for industrial countries and destabilizing for underdeveloped "export economies." Cf. C. P. Kindleberger, Foreign Trade and the Nationat. Economy $2 \times 2 \mathrm{ff}$. (1962). Where such basic conflicts exist, little can be expected from commodity agreements except when they are constructed as some form of "foreign aid." In that case, they can hardly be considered as the outcome of negotiation in the normal sense. Instead, they may be seen in the context of efforts toward international development planning. 
two levels: first, the process of negotiation and bargaining leading to agreement under specific terms as to coverage, timing, administration, costs, and so on; and secondly, the effects of the agreement under such terms.

Among the special problems involved in such a two-level approach would be the existence of important feedbacks from expectations and anticipations of effects into the negotiations themselves. Even after agreement has been reached, there remains a high degree of instability because of the possibilities for correction and, ultimately, of drop-outs and complete lapses. It is assumed that this basic instability of commodity agreements need not imply their uselessness. In any case, no attempt can be made here to analyse the process of negotiation. Reference to the beginnings of a formal theory of negotiations as a development of the theory of oligopolistic markets, and to theories on conflict resolution, must take the place of any such attempt. ${ }^{4}$ In limiting our discussion to the multilateral agreements, including both exporting and importing countries, another exclusion of convenience seems legitimate: there need not be any discussion of the pure forms of governmental cartels as unilateral producer-seller (or importer-consumer) agreements. The economics of such arrangements are not sufficiently different from the economics of their private versions to make the textbook treatment of the latter inapplicable to the former. ${ }^{5}$

The incidence of gains from cartelization may differ and public cartels may be politically more acceptable than private cartels. Therefore, some intergovernmental commodity agreements of the cartel type may derive their major justification from the fact that they substitute for otherwise existing or "inevitable" private cartels.

Even if cartel type agreements are disregarded, there can be no doubt that commodity agreements, if effective, interfere in the commodity markets covered and, via the interdependence of markets, in other markets as well. Such interference may, however, be designed for minimal distortions if "market conform" methods are chosen. The three typical methods considered rank differently in this respect. But there is, in principle, no inconsistency in the view that "competition by agreement" shall rule a market-or even, that coercive forces shall be brought in to enforce it. ${ }^{6}$ The market, as it is, may-and regularly does-contain the results of various distortions due to both private and public "policies," of which tariffs and quotas, on the one hand, and private collusion, on the other hand, merely represent the most obvious examples.

By the same token, there is no inconsistency in the view that intergovernmental commodity agreements may supplement market forces to alleviate severe short-run

“Cf. M. Shubik, Strategy and Market Structure (I959); W. Kreile, Preistheorie (I96i); K. E. Boulding, Conflict and Defense, A General Theory (1962).

For the relationship between monopolistic pricing policies and economic stability, opposite viewpoints are represented by J. A. Schumpeter, Capitalism, Socialism, and Democracy (I942), and Machlup, Monopoly and the Problem of Economic Stability, in Edward H. Chamberdain (Ed.), Monopoly and Competition and Their Regulation 3-187 (I954).

'There is no question, of course, that agreements are inconsistent with "frec private enterprise" in the stricter sense. 
fluctuations in prices and export proceeds where they persistently arise. But the choice of methods is extremely limited and the criterion of negotiability is far from sufficient to ensure economically positive effects-at least, as long as negotiators, too, are hampered by incomplete foresight. The Havana Charter made comprehensive administrative provisions for commodity agreements. The economics of such agreements have received only sketchy treatment, or have been given merely for individual cases. Characteristically, proposed agreements tend to have much broader aims than mere price stabilization. However, price instability regularly provides the basic argument; only it then tends to get lost in more ambitious attempts at formulating more comprehensive tools of long-run international development policies.

This tendency, rather than the absence of cases to which commodity agreements of a narrower but still useful scope could be applied, may well explain the notoriously small number of successful negotiations in the years after World War II. Chances for more commodity agreements might be greatly enhanced if they could be viewed as of narrower aim and of transitional nature, particularly at a time when wide sectors of international trade are already subjected to transitional schemes of one kind or another, e.g., the European Coal and Steel Community (ECSC), the European Economic Community (EEC), and the United States Trade Expansion Act of Ig62. ${ }^{6 a}$

From this point of view the Havana Charter does not recommend itself as a basic document. It implies strongly the need for permanent arrangements; also, the empirical context to which it is drawn with its heavy reliance on depression and wartime conditions is not sufficiently typical. Even where the Charter mentions the specific goal of price stability, it is hard to accept its basic objective, ${ }^{\top}$

... to prevent or moderate pronounced fluctuations in the price of a primary commodity with a view to achieving a reasonable degree of stability on a basis of such prices as are fair to consumers and provide a reasonable return to producers, having regard to the desirability of securing long-term equilibrium between the forces of demand and supply.

Instead, a starting position is needed which is more limited in its objective and at the same time of broader scope: more limited because the ambiguous concepts of "fair prices to consumers" and "reasonable returns to producers" unnecessarily burden an argument as long as it is not intended to make a case for a complete remodeling of the market economies participating in international trade; and of broader scope because price instability cannot be viewed simply as a characteristic of primary product trade.

Narrowing the task of commodity agreements to an objective of mere price (instead of "fair" price) stabilization does not lead straight to a general theory. It certainly cannot be assumed that even such a narrower goal of price stabilization does not entail an element of income redistribution. A selective and neutral price

a 76 Stat. 872 , I9 U.S.C.A. $\$$ r80I et seq. (Supp. I963).

'U.S. Dep't of State, Havana Charter art. 57(c), March 24, I948. 
policy is, indeed, impossible. The distinction remains, therefore, one of differences in the degree of market intervention. Such differences may be important enough. In any case, there must remain wide selectivity with respect to markets which can be made subject to price stabilization agreements. The choice of those markets in which trade of underdeveloped countries accounts for a conspicuous share, and on the prices and volumes of which relatively large shares of their incomes depend, need not be made on the basis of instability alone. Supplementary criteria may be-and regularly are-introduced. In fact, there is nothing inconsistent in singling out for price stabilization schemes markets which by the criterion of instability alone do not command a high priority. However, lest such problem orientation lead to often unwarranted proclamations of special "laws" inherent in the objective characteristics of either special commodities or of special trading relationships between countries in different stages of economic development as such, it may be useful to point to the more general phenomenology of market instability. 8

There is a wide roster of commodities with high degrees of instability in prices and volumes. Based on their performance in international trade (of the noncommunist countries, I948-r958), it appears that base metals had the highest measured instability, while agricultural raw materials had the lowest. Export values of capital goods, food, and base metals together contributed most to the overall instability in world export values. Primary products as a group fared better in this respect than did manufactures. If weighted by the respective world trade shares of these two commodity groups, manufactures turn out to contribute about two thirds of the world export instability. The instability so measured does not reveal the direction of changes. Changes in relative prices between commodity groups may be

${ }^{8}$ The alleged rule of different economic laws has led to pronouncements of rather varied types. To show objectively special problems of trade in primary products, general theories of the old as well as the new orthodoxies have described a full swing from one extreme position to another: as different principles of production were seen to apply to primary and secondary products, primary products were said to be bound to benefit from a secular improvement in their terms of trade vis-d-vis manufactures. The former were to enjoy the advantages of increasing relative scarcity due to diminishing returns from limited resources. Conversely, they were seen to suffer inevitably a deterioration in their terms of trade due to the prevalence of conditions typical for underdevelopd countries, namely, underemployment and inability to absorb domestically the productivity improvements realized in export oriented primary production. Neither of these positions on secular trends seems maintainable as a general theory. The role of capital in primary production on the one hand at least partly compensated the effect of diminishing returns from limited natural resources; the possibility of economic growth transmission from export sectors to import competing sectors and the intrasectoral mobilization of factors of production on the other hand must still lead to gains in the real income generated from primary production-at least in the course of economic development. Both effects will tend to counteract a continuation of foreign "exploitation" through market mechanics as expressed in a deterioration in the underdeveloped countries' terms of trade. Theoretical and empirical indications are that economic inflexibility, indeed a definition of economic underdevelopment, rather than special characteristics in production and/or consumption of primary products explain the actually unfavorable development in the terms of trade of underdeveloped countries. Cf. J. Tinbergen, Shaping the World Economy (1962). In this context, it might also be remembered that virtually all countries are producers and consumers of primary products. The share of primary products in world exports has increased more rapidly for industrialized countries than for non-industrialized countries. Since 1958, industrialized countries have exported to each other larger amounts of primary products than non-industrialized countries exported to them. GATT, INTERNATIONAI. TRADE, I961, at 23-24 ( 1962$)$. 
accentuated or mitigated. The instability in the terms of trade between primary products and manufactures was, in fact, higher than instabilities in the absolute export values of either commodity group during the same period. ${ }^{9}$

While this picture would seem utterly perplexing in view of widespread belief in the inherent instability of primary products trade, it is more in line with expected patterns when focussing on the performance of individual commodities of the group. There, the familiar list emerges, containing pulp and paper at the top (index 4T.4), followed by rubber (40.3), jute bagging (39.6), and at the end of a list of twenty-nine commodities comprising thirty per cent of world exports in the mid-I950's, bananas (9.3), butter (8.3), and fish (6.5). Pulp and paper, rubber, wool, wheat, cotton, coffee, and petroleum (with individual instability indices declining in that order) accounted for more than half of the total instability contributed by the twenty-nine commodities. If price instability as such rather than export value fluctuation is taken as the criterion, a ranking in order of declining instability shows cocoa, rubber, and pulp and paper at the top, and bananas and tobacco at the bottom of the list. The expected is also largely confirmed when it comes to instability of export values for individual countries. Here again, one may be surprised to find the largest percentage contributors to total export instability are (in that order for the period under review) the United States, United Kingdom, West Germany, U.S.S.R., France, and Japan-countries accounting for just under half of total world exports and for the same percentage of export instability. But among the countries with highest individual instability indices for exports (the first quartile in a ranking of eighty-three countries) underdeveloped countries predominate by far. Furthermore, the countries with the most frequent downward movements in export proceeds during the same period are underdeveloped countries with the conspicuous exception of the United States and Canada, which are found in the same group. ${ }^{10}$

For the "inter-war" years and again for a shorter more recent period and in terms of indices measuring not just annual variations as such but also changes in relative prices, statistics give a rather less favorable picture for primary products as a group, with a clear downward movement in the terms of trade vis-à-vis manufactures. Also, the general impression that primary product prices tend to fall more than manufactures prices in general business down-turns still stands. ${ }^{11}$ But

\footnotetext{
${ }^{\text {o }}$. D. Coppock, International Economic Instability-The Experience After WorLd WaR II, at I4I (1962). The method used in this study is to measure year-to-year relative changes corrected for influences and expressed by logarithmic variance indices.

${ }^{10}$ Id. at 142 .

${ }^{11}$ P. Lamartine Yates, Forty Years of Foreign Trade (1959). An indication of the magnitude of the problem as seen in review of the r930's may be found in League of Nations, 'THE Transition OF WAR to PeAce Economy 23 (r943): "During the last twenty years the price of wheat and of jute has been halved three times within about twelve months, the price of cotton three times in periods of under eighteen months, the price of copper and of lead was halved four times within periods of two years and doubled three times even more rapidly. . . Between 1920 and 1933 the price of crude rubber fluctuated between four cents a pound and twenty-five times that amount and was on several occasions
} 
for policy purposes no firm long-run tendencies toward greater instability of primary product trade can be inferred from all such evidence. As preliminaries to a theory of price and export stabilization these findings do not, on the other hand, imply a tendency to belittle the urgency of a stabilization scheme for exports of underdeveloped countries. Indeed, they may well help to clear the way toward negotiation. While one special argument may be lost, this also relieves the advocates from the extra burden of having to claim that high export instability proves the inapplicability of general economic rules to countries in the earlier stages of economic development. There remains enough common ground for both highly developed and underdeveloped countries when it is concluded that ${ }^{22}$

high export instability is postively correlated with instability of export quantum, instability of import outlays, instability of export prices, and instability of terms of trade; it is negatively correlated with geographic concentration of exports, foreign trade per capita, GNP per capita, foreign trade as per cent of GNP, and energy per capita.

Among other variables associated with instability of exports, the rate of economic growth and the variations in the international flow of capital also turned out to be significant. ${ }^{13}$

Every one of the economic aspects of the problem for which a significant negative or positive correlation with instability can be shown to exist should, ideally, be incorporated into the set of conditions and relationships from which an economic theory of stabilization is to be derived. Their causal connection, however, is not established by the mere existence of a correlation. Ultimately, a judgment has to be made with respect to the selection of most relevant aspects and their priorities in the causal nexus. That must be true even in the purest of cases; it is more obviously true when a theory is to "explain" relationships between variables taken from situations of substantial market imperfections. It is on these grounds that a general theory of commodity agreements should not be expected: the analysis of the potential effects of such agreements presupposes a particular view as to the "causes" of the problem to be solved. And these causes are likely to be as manifold and varied as the

doubled or halved in the space of a few months." For 1959/6r the following indices of unit values or prices of selected commodities may serve as examples.

$\begin{array}{lcc} & (1934-38=100) & (1950-52=100) \\ \text { Aluminium } & 127 & 140 \\ \text { Copper } & 321 & 134 \\ \text { Coal } & 259 & 96 \\ \text { Cocoa } & 515 & 93 \\ \text { Tin } & 215 & 92 \\ \text { Wheat } & 200 & 84 \\ \text { Sugar } & 235 & 82 \\ \text { Coffee } & 393 & 69\end{array}$

Source: UNITEd Nations Commodity SuRvey, I962 (UN Pub. Sales No. 1963.II.D.3).

${ }^{12}$ Coppock, op. cit. supra note 9, at $\mathrm{I} 43$.

${ }^{13}$ Among the more obviously important other findings of Coppock's study, we mention only that a country's high rate of participation in international trade by itself typically goes together with relatively low instability of exports for that country. This is, in part, strong support for arguments in favor of trade diversification. See also, in the same sense, TINBERGEN, op. cit. supra note 8. 
number of special situations. Typically, it is the combination of otherwise quite harmless aspects which creates the problems to which commodity agreements are meant to be addressed.

\section{I}

\section{Buffer Stock Operations}

If market conformity is to be observed, the price stabilization goal of commodity agreements can never mean state trading, quotas and other quantitative restriclions, price fixing, or price maintenance in the face of shifting long run demand or changing conditions of production (including marketing). The scope of price stabilization is then limited to the smoothing out of such fluctuations which result merely from "overreactions" on either side of the market, i.e., from "mistakes" in the allocation of resources arising because of (a) absence of knowledge with respect to the current conditions and future developments of "the market" on the part of all market participants; (b) absence or insufficiency of institutional arrangements to provide (at a cost) cover against at least part of the risks entailed in fluctuating prices. The first of these two conditions must be taken in its broadest sense, implying differences in pricing power as a result of asymmetrically dispersed knowledge among the market participants. The institutional nature of the second condition implies the possibility -and indeed the likelihood-that the problems to be solved are transitional: higher stages of economic development in market economies tend to produce effective mechanisms for covering risks as specialized markets ("futures"), and instruments of speculation and insurance emerge.

Clearly, the price fluctuations to be smoothed cannot be thought of as that element of price flexibility characteristic of market economies at their best. The issue is confused when stabilization policies are objected to on the ground that they destroy this essential flexibility. Instead, it might be argued that stabilization merely seeks to cope with such variations in prices as arise from the rigidity of markets. Conversely, it might be stated that price flexibility makes price fluctuations unlikely. The crucial distinction is that between price level changes and changes in the structure or interrelationship of prices in various markets.

Some of the salient features of price instability which serve no useful purpose are contained in the so-called cobweb theorem. This textbook model was developed out of the empirical behavior of the hog cycle, but it is useful for the analysis of similarly fixed production and gestation periods in other industries as well. It traces for conditions of perfect competition the price-quantity adjustments from one production period to the next, showing the various possibilities for adjustment lags in production leading to either self-correcting or explosive, unstable market-price movements. The crucial characteristics determining the type of path described by the price movements are the relative slopes of demand and supply curves, i.e., their relative price sensitivity. In the "worst" case, when the curve describing price- 
quantity responses in demand over the multi-period process is steeper than the curve describing price-quantity responses in supply, the price instability (upwards and downwards) and the creation of excess supplies and excess demands at given market prices tends to be cumulative. ${ }^{14}$

Given the impact of other factors besides prices (incomes, tastes, prices of other goods, and so on), it cannot be assured that the same markets will always behave in the same fashion. But there nevertheless is convincing evidence for the existence of separate business cycles of certain commodities, displaying a movement of prices and quantities in opposite directions so that maxima for prices are reached when minima for quantities are sold, and vice versa. Relevant examples are provided by coffee, and, in general, by markets in which inventories and therefore speculative elements are important. In the case of many agricultural products, however, a systematic connection to cyclical fluctuations is difficult to detect and may not in fact exist. ${ }^{15}$

If the role of commodity agreements is to be limited by the requirement of market conformity, it amounts to no more than the provision of institutional mechanisms for the temporal spreading of prices where this is not accomplished by the market itself. It may then turn out that the major effects are pre-empted before the agreement is concluded: the negotiations may have provided such a dispersion of relevant information that overreactions are reduced to that quantity of trial and error with which all markets can be expected to cope. One might even be tempted to say: the longer the negotiations take the better. In that case a rather optimistic appraisal of recurrent experience with slowly progressing negotiations becomes possible. Under such an approach, price instability is likely to be damped, but it certainly cannot be expected to disappear. ${ }^{16}$

The working principle of a buffer stock or equalization stock scheme makes it the only form of commodity agreement which fulfills the requirement of market conformity in the above sense. The agreement would have to provide for a central agency acting as a "speculator" in the commodity market concerned. Purchases and sales in "the market" would constitute the only policy tool. The criterion of its application would be a price range with upper and lower "intervention" points. The

16 The cobweb theorem assumes that producers do not learn from experience, or at least that they do not learn enough. Present prices are taken as the basis for production decisions.

${ }^{25} \mathrm{~J}$. Tinbergen \& J. J. Polak, The Dynamics of Business Cycles $233 \mathrm{ff}$. (x950). These authors also quote E. WAGEMANN, NARRENSPIEgeI DER STATISTTK 266 (I942), as reporting that the introduction of rigid price fixing did not prevent the fluctuation of hogs supplies in Germany during the I930's.

${ }^{20}$ Preparations by the International Tin Study Group for a new agreement on tin started in 1946 ; negotiations began in 1948. They were concluded in 1954, and the agreement became effective in 1956. Although two important consumer countries (the United States and West Germany) did not accede to the Agreement, it is said to have "no doubt contributed to price stability." Tinsergen, op. cit. supra note 8, at 79. Greve, Rohstoffabkommen fïr Zinn, Tee, Kautschuk und Zucker, ri 8 ZEITscFrIFT F. DIE GesaMte StaAtswissenchaft 733 ( $x 962$ ), finds it too early to attempt a statistical assessment of the effects of this agreement. Earlier tin agreements (I93I, I934, I937) seem to have contributed little to price stability. Cf. Greve, supra, and George W. Stocking \& Myron W. Watrins, Cartels or Compettiton, The Economics of International Controls by Business and Governarent i67 ff. (1948). 
basic limitation to its functioning would be the availability of funds in time of price declines and need of supporting purchases, and the availabilty of commodity stocks in times of rising prices and need of damping sales. The simplicity of the principle should not be allowed to belittle the technical problems, particularly of sharing the cost of financing and of setting the relevant price range. In general, the sharing of the cost between producer and consumer countries may be justified by the argument that both tend to benefit, for importers in many cases tend to buy most when prices are rising, and to reduce purchases in periods of declining prices. The total cost of holding and manipulating stocks need not be greater than it would have been without the scheme. Indeed, with a successful operation of the buffer stock, the total of all stocks held on average by producers and consumers may well decline. For if some private stocks are accumulated as a result of erroneous private speculation in the face of highly unstable prices, the extent to which the agreement reduces such instability must in itself reduce the frequency of such mistakes. In determining the range of prices, seasonal factors have to be allowed for. In general, the narrower the range between the agreed-upon intervention prices, the greater will be the stabilizing effect of the scheme. With a narrower range, however, the volume of stocks or the rate of turnover of such stocks officially held tends to increase. So will the cost of the scheme tend to increase, and disproportionally to the sources of self-financing out of profits.

The logical point to start building up stocks would be in depression. In any case, the provisions for stocking and financing may give the scheme either a restrictive or an inflationist bias: if the participation in the scheme provides for each country's share in total stocks and total financial resources on the basis of standard world exports, a larger proportion of "cash" in the initial "endowment" of the buffer stock agency will make for a price raising bias; and a larger proportion of commodities to cash in the total endowment will make for a restrictive bias. No effective use of buffer stocks can be expected for periods of predominantly falling or rising prices unless the price range is subjected to frequent revisions. Only if the price range is "out of touch" with the trend will it render the scheme ineffective as the stock runs out of commodities (persistent price rise) or cash (persistent price decline). The more frequently the price range is revised and the greater the weight given to the more recent market prices, the longer will be the life expectancy of a buffer stock scheme, but the smaller will be its importance as price stabilizer.

Occasionally, the case for commodity agreements as price stabilizing devices has been connected with proposals for international commodity standards. ${ }^{17}$ This seemingly ingenious plan would make a "basket" of selected commodities take over the role of gold in international finance. Currency would be issued only in fixed proportions to a fixed combination of warehouse receipts for raw materials, and would be redeemable in such materials. During depressions, this would tend to stabilize

${ }^{17}$ Cf. Benjaman Graham, Storage and Stability (1937); Frank D. Graham, Social Gonis and Econosire Institutrons (1942); Hayek, A Commodity Reserve Catrency, 53 Econ. J. 176 (1943). 
the demand for such materials; and during boom periods, the limited availability of such "reserves" would provide a desirable constraint on price increases. The overall aim would be "to make controls [of prices] subject to a mechanical and predictable rule."18

Apart from objections to the principle as an instrument of international finance, and apart from questions as to its technical efficacy as a general price level stabilizer, the average price stability of the commodities included in the basket is almost certain to be increased under such a scheme. However, in view of the often pronounced differences in the critical conditions of supply and demand for different commodities-and even for the same commodity produced and consumed in different countries-the application of the plan is likely to lead to a rather arbitrary distribution of the "gains" from such stabilization.

In any case, neither a commodity standard nor buffer stocks can be seen as substitutes for general anti-cyclical policies. If, on the other hand, inventory cycles with their particular role in general business fluctuations are considered, the buffer stock with its specialized effects rather than the commodity standard with (at best) stabilization of averages for many commodities may be seen as an integral part of anticyclical policy. If importers' inventory changes are the primary "cause" for price fluctuations and if they, in turn, are responses to changes in expectations of future supply, cost, and final sales, an intergovernmental buffer stock is likely to alleviate the price fluctuation-especially when there are pronounced differences in the length of typical ordering periods between orders for foreign and for domestic supplies. Nevertheless, all forms of price stabilization remain secondary to more direct attacks on the underlying forces of instability, not the least of which may be the fluctuations in autonomous government demand in different countries. Anticyclical timing and allocation of government expenditures are almost certain to contribute more to price stability than intergovernmental buffer stock schemes which at best may provide some alleviation.

The general case for price stabilization through buffer stocks may be summarized. It is strongest

(I) where the main cause of price fluctuations lies in speculative changes in demand and where speculators are often wrong: ${ }^{19}$

(2) where production periods are relatively fixed and long;

(3) where the sensitivity to price changes in demand and/or production is low, so that it takes relatively strong price impulses to bring about an adjustment in quantities; ${ }^{20}$

${ }^{18}$ Hayek, supra note 16 , at 184 .

${ }^{10}$ That, again, suggests a transitory nature of the problem for any one given commodity, since it is hard to believe that speculators as a group should not learn from experience or that they should be able to sustain continuous mistakes.

${ }^{20}$ This applies 2 fortiori to cases of temporarily perverse responses. The behavior of certain agricultural crops at the beginning of the depression in the United States is usually referred to in this connection. Acreage and production increased somewhat even while prices fell. As a basis for economic 
(4) where the long-run market trends are comparatively stable. (Not that it were necessary for these trends to be upward. Even with low income elasticities, i.e., with declining shares in total consumption expenditure out of a rising total income, the smoothing of the oscillations around the trend can be seen as the target of stabilization operations). ${ }^{21}$

Finally, if success of a buffer stock scheme is to mean an improvement of the conditions conducive to more rational planning by private and public households and firms,

(5) the "world market price" on which the manager of the buffer stock is to base his operations must reflect "normal" transactions.

For the limited goal of price stabilization, there is no need that total world production and consumption be covered by the agreement; nor is there any implication of complete abstinence for all countries from independent stockpiling policies. That is to say: the more comprehensive the coverage, the safer will be the buffer stock, but it lies in its nature as as palliative rather than a cure that it will follow the trends even of imperfect world markets. Large scale and unpredictable transactions (e.g., for stockpiling) by countries not regularly participating in international trade or not proportionately participating in financing and supplying the buffer stock are likely to render the buffer stock inoperable. A "world market price" is safe enough as a basis for price stabilization when its average annual changes are such that they correctly represent the market trend. The smaller the amounts withheld from the market by autonomous policy of either member or nonmember countries, the more suitable the market price will be as a basis on which to set the range between upper and lower intervention points. ${ }^{22}$

Even where conditions in the above sense are favorable-and with the obvious

policy, such evidence of negatively sloped supply curves may not be sufficient. Even on the question of "low elasticity of supply with respect to price changes" as founded in the relative inflexibility of certain lines of agricultural production the evidence is by no means conclusive to establish firm generalizations. Compare the conflicting findings of Porter, Comment, II KrmLos 23I ff. (1958), and Stern, The Price Responsiveness of Egyptian Cotton Producers, 12 id. 375 ff. (1959). Cf., more generally, the discussion on elasticity-pessimism in international trade; Harberger, Some Evidence on the International Price Mechanism, 65 J. PoL. Econ. 506 (1957). There is certainly a strong presumption that agricultural products as a group are produced under conditions of lower short-run price elasticity than manufactures as a group. There remain, however, important qualifications as to differences from commodity to commodity. Also, the relevant elasticities of demand facing a firm in the exporter country are influenced by the relative size of the producer country in terms of its share in world production and trade, and vis-à-vis individual countries. Last but not least, the share of the domestic market in the total market for the exportables must be considered.

21 The condition of stable trends is probably met by most basic foodstuffs where annual production totals may fluctuate unpredietably but where long run trends of production possibilities and consumption requirements are less likely to be out of line than supply and effective-demand. However, the commodities ranking highest on the list of price instability can hardly be found in this category. Neither cocoa, nor coffee, nor rubber can claim a basically certain future in terms of either their shares or their absolute positions in the consumption and use pattern of industrialized and/or newly developing countrics.

${ }^{22}$ In this connection, it is of interest that for more limited tasks, nationally administered buffer stocks operated in várious European countries using either specific or floating price ranges. 
requirement of storability fulfilled-and even where the scheme is successful in reducing fluctuations in the price of the commodity covered, the buffer stock is in itself powerless to cope with problems arising out of general price level changes which tend to impair the asset value of existing stocks. Furthermore, mere price stabilization still does not mean that operation of the scheme will be neutral with respect to real income distribution. Since only the most summary kind of compensation for such income effects is provided through agreed-upon allocation of total cost of the program, other measures may be called for.

It is typically where prices, quantities, and sales proceeds at a given foreign exchange rate do not move in fixed proportions and in parallel direction, that instability is the most urgent problem. Where either demand or production fluctuations dominate in causing a fluctuation in prices, it is not at all clear whether prices, quantities, or sales proceeds "should" be stabilized. If prices rise as a result of increased demand (with unchanged supply), quantities may and sales proceeds must also increase. ${ }^{23}$ If prices rise as a result of decreased supply (with unchanged demand), quantities must decrease but sales proceeds may either decrease, increase, or remain unchanged. In this case, successful stabilization can mean destabilization of income. As a further complication, the price change in itself may not give an indication of the price "signal" which is actually received by the producer or the final consumer, who are, after all, the ultimate "adjusters." Behavioral and structural characteristics of a more complex type than that suggested by mere price mechanics have to be considered if an economic appraisal of price stabilization is to be attempted.

If more is wanted than buffer stocks can accomplish by way of stabilizing international trade, they need not be discarded; for they can serve as a supplement to whatever other measures may be indicated.

Under certain conditions it can even be argued that other types of commodity agreements require buffer stock agreements as supplementary devices if they are to succeed. Take, for example, a long run contract between all producer and all consumer countries of a given commodity, and with guaranteed purchases and sales at prices within a range sufficiently narrow to effectively prevent price fluctuations which "normally" (i.e., without the agreement) would appear. This must lead to temporary market shortages and surpluses if there is a problem of short-run inflexibility, i.e., short-run fluctuations, to begin with. In this case, some buffer stock scheme would appear to be necessary.

\section{II}

\section{Commodity Control Agreements}

If a "normative" element such as "fair prices," or "equitable returns" is made a primary objective of commodity agreements, "market conformity" can no longer be maintained, were it not used in an entirely different meaning. It may be legiti-

\footnotetext{
${ }^{23}$ In the extreme case of perverse supply, sales proceeds may decrease even under these conditions.
} 
mate to understand market conformity in terms of ideal markets rather than in terms of the often distorted markets of reality. More useful, however, is a clear distinction between those agreements which are designed merely to support and to supplement the market mechanism such as it is, and those designed to alter both market processes and market results. The Havana Charter introduces the term "commodity control agreements" for this latter type. ${ }^{24}$

Economically, these agreements are not to be pre-judged merely by reiterating the superiority of free trade solutions. For the theorem that free trade is better than restricted (controlled) trade hinges on a set of rather special conditions, so that for policy purposes, a second-best argument usually is indicated. In any case, controlled trade is "better" than no trade, and if a particular pattern of real income distribution is aimed at, either for reasons of "justice" or "spoils," or simply in view of particular requirements for maximum economic growth, restrictive trade may be better than free trade.

With control type agreements, a host of problems is encountered which by far surpass the mainly technical problems found in buffer stock schemes. Not the least of such problems lies in the possibilitity of a price destabilizing effect of a long run agreement. ${ }^{25}$

If long run contracts between producer and consumer countries provide for a minimum price at which consumer countries guarantee purchases of specified quantities up to a predetermined maximum, it is not at all certain that either prices or export proceeds will be stabilized.

Let it be assumed that either not all producer and consumer countries participate, or that all participate but there is effective demand and supply for quantities and prices beyond those effectively covered by the agreement. Also assumed are perfect competition and increasing cost. Essentially, then, the possibility of destabilization depends on the existence of two levels of prices at any one time: the price resulting from effective operation of the agreement, and the prices resulting from transactions outside the agreement. The point can most readily be made when both price and maximum quantities are fixed under agreement. If lower prices were to prevail outside-a possibility against which the agreement was presumably to protect the participants-the effect is not simply that consumer demand will shift for supplies above the contracted maximum to "outside" sources. Rather, as consumers are already paying more for their contractual purchases than they would in the absence of the agreement (this assumes highly competitive conditions as the only alternative to agreements), real income available for purchases beyond the contractual amount is smaller than it would otherwise have been. Consequently,

${ }^{24}$ In the language of the HAVANA CHARTER, art. 6I, these are intergovernmental agrecments aiming at "(a) the regulation of production or the quantitative control of exports or imports of a primary commodity and which has the purpose or might have the effect of reducing, or preventing an increase in, the production of, or trade in, that commodity; or (b) the regulation of prices."

${ }^{25}$ Johnson, The De-Stabilizing Effect of International Commodity Agreements on the Prices of Primary Products, 60 Econ. J. 626 (x950). 
purchases beyond the contractual amounts are reduced below what they potentially would have been for any price below the agreement price. If prices "outside" were higher than the agreement price at which a minimum quantity must be bought, and there potentially is an effective demand for amounts beyond the guaranteed purchases, the income effect of higher prices will be less restrictive than it would have been in the absence of an agreement. Ceteris paribus, additional purchases will be greater at any price above the agreement price.

In both cases, a destabilization of prices may result. In the one case, prices will tend to fall more as a result of a lower price elasticity in the relevant downward range of demand; in the other, prices rise more as a result of lower price elasticity in the relevant upward range of demand. The tendency for such destabilization of prices will increase with the (positive) income-elasticity of demand (i.e., as income changes, demand changes in the same direction) for the commodity in question, the share of expenditure on this commodity in total expenditure of the consumers, and the proportion of total trade in the commodity covered by the agreement.

There is, however, a mitigating effect implied in the last condition: the greater the proportion of trade in the commodity which is covered by the agreement, the narrower will be the base on which the tendency to destabilize prices can become effective. Furthermore, some mitigating effects may come from shifts in supply. ${ }^{28}$

If no such shifts (i.e., willingness and ability of suppliers to sell greater or smaller quantities at the same prices, or the same quantities at higher or lower prices) are allowed for, the destabilization in prices must at the same time mean a destabilization of sales proceeds.

In many instances, commodity control agreements are argued in terms of this latter criterion, or still more specifically, in terms of sales proceeds in foreign currency, or in terms of export prices relative to import prices (given the rate of exchange).

Problems of this kind-rather than price stability questions-attain special importance when market responses are asymmetrical for upward and downward movements of prices. Price rises may find highly elastic output and supply responses while lagging supply adjustability may be associated with price declines; or demand may be inelastic with respect to price decreases, and elastic for price rises. In this way, demand and supply may be biased against trade. Again, it is to be noted that such characteristics of demand and supply express only in part technological limitations or "economic laws"; a larger part may reflect sociological, behavioral conditions. If this is combined with low income elasticity of demand and with cost reductions in production and marketing due to technological and institutional development, a case for international commodity control agreements may be made. A purchase contract type

\footnotetext{
${ }^{20}$ But the income distribution between producers and consumers which is implied in the effective limitation of maximum-price purchases may also result in a further aggravation of the price destabilization: if the producer industry is forced below optimum output, each quantity will be supplied at higher prices.
} 
agreement may then not be considered as entirely self-defeating even if it leads to a greater effective price instability. A preoccupation with the maintenance of critical minimum levels of export proceeds rather than with optimal efficiency can be legitimate at least for short run policy purposes. How far this argument can be extended, however, depends on empirical rather than theoretical conditions. In general, the case for control agreements will be the stronger the less it relies on protective arguments as such, or the more it relies on a maximization of the economic gains from trade.

Unfortunately, there is no entirely unambiguous indicator of changes in the economic gains from international trade. The traditional concept of "commodity terms of trade" or "net barter terms of trade" provides only a rough policy guide since it does not reveal the causes of the changes which it measures. Terms of trade variations almost always reflect changes in domestic and foreign conditions of production, consumption, and trade. Index and other statistical problems apart, a deterioration in the ratio of export to import prices in one particular line of trade may reflect changes within each country which on balance increase the standard of living.

Instead of comparing export prices with import prices (or export and import price indices), an expression may be needed for changes in a country's capacity to import in terms of its expert proceeds. The "income terms of trade" (commodity terms times export volume) give a more useful measure for this purpose. If productivity changes in the export industry are to be allowed for, the "single-factoral terms of trade" (commodity terms times export productivity index) are used. Changes as measured by these different statistical devices may differ in degree and direction, and positive or negative changes in economic welfare may be associated with deterioration as well as with improvement of the terms of trade. But for individual countries, this always implies an international income redistribution or a different participation in the economic gains from trade compared with what it would have been, given the conditions from which the change originated, but without the change in the terms of trade. Tentatively one might say: deteriorating terms of trade (in either sense) imply a declining marginal importance of international trade.

Under conditions stipulated in competitive models, there is a strong presumption that such a change is likely to lead to conflicts between trade and economic development; economic development may be associated with a deterioration in the commodity terms of trade. Only if economic development displays an "anti-trade bias" will the terms of trade of an export country (in a two-country, two-commodity model with incomplete specialization in consumption and production) tend to improve. The possible deterioration in the export country's terms of trade will be minimized when there is an "import-bias," i.e., when demand for imports increases less than proportionately to the increase in domestic income. It will be maximized when there 
is an "ultra-export-bias," i.e., when the absolute demand for imports increases more than total domestic income. ${ }^{27}$

When economic development occurs in both countries in the same model, the change in terms of trade depends on the rate of increase in each country's demand for imports from the other. With equal direction-but different degrees-of development-bias in both countries, the terms of trade deteriorate for that country which has the higher rate of growth in demand for imports as well as in income.

In this sense, the rationality of trade controlling (restrictive) measures may merely depend upon considerations of possible retaliations. In the absence of such measures on the part of other trade participating countries some unilateral trade restrictions may be preferable to free trade for the country in question. For the world economy as a whole, a judgment must depend on whether the deterioration in one country's terms of trade is the result merely of market exploitation in the sense of "market exhaustion" or, instead, of exploitation in the sense of prevailing market power exercised on the part of importer countries vis-à-vis the exporter country. Terms of trade deterioration in the former sense serves as a market indication for the direction of economically necessary shifts in production and/or consumption in the exporting country. No such implication need be present when the deterioration in terms of trade is the result of private or public market power on the importing side.

Kindleberger's recent suggestion that a preoccupation with the terms of trade may be an indication-in developed countries as well as in those newly developingof insufficient "capacity to transform," i.e., "an implicit acknowledgment that the country does not reallocate rapidly to take advantage of price changes, applies only in the former case. If the exporting country as a whole sells in highly competitive markets and buys its imports in markets characterized by a relatively high degree of monopolization both in the markets for final products and in the markets for factors of production (e.g., labor), deteriorating terms of trade cannot easily be interpreted as valid economic signals indicating the need of shifts in production for efficiency's sake. There is the problem, of course, that one would have to argue that the degree of monopolization is increasing during the period considered. But the argument cannot be discarded by saying that "the existence of such monopoly elements would at most explain movements in the absolute domestic price level and not changes in relative world prices" of internationally traded commodities because "world price levels depend on world conditions of supply and

${ }^{37}$ The use of term "anti-trade bias" is H. G. Johnson's. Johnson, Economic Development and International Trade, Nationalфkonomisk Tidsskrift, pts. 5-6 (I959), and H. G. Johnson, INternational TrADE AND Economic Growth 76 (1958). The other terms ("export-bias," "import-bias") have been used since J. R. Hicks introduced them in An Inatigural Lecture, OXFord Economic Papers MI7-25 (June 1953). For an exposition of the relevant analysis, see Black \& Streeten, La balance commerciale des termes de l'échange et la croissance économique, ro Economie AppLiqueE 299-322 (r957). For a summary of the neoclassical position on trade and economic development, compare G. M. MEIER, INTERnational Trade and Development ( 1963 ).

${ }^{28}$ C. P. Kindleberger, Foreign Trade and the National Economy ilz (1962). 
demand."29 Such reasoning is inadmissable as long as individual countries retain some locational characteristics which provide for some degree of economic rationality among the reasons of their existence as independent countries, and as long as autonomous economic policy (monetary, fiscal, and commercial) remains possible. There is, for these reasons, a tendency for national demand and supply to be less price elastic than "world demand and supply."

It remains nevertheless true that "if resource allocation can take place in response to price changes, the relationship of export to import prices declines sharply in importance."30

Commodity agreements which rely on output and/or export restricting quotas would violate ideal market patterns even more severely than those relying on manipulated prices. ${ }^{31}$ Quotas are more certain in their effects as measures of intervention than are those instruments which operate through price responses. Their economics can nevertheless be treated in analogy to the case of tariffs. There will be the familiar protective, consumptive, and redistributive effects. And even the revenue effect may be present in the same sense in which it appears under a regime of tariffs: if export licenses are auctioned off by the quota-imposing government (or, in the case of international agreements, by an international agency), the proceeds of such auctions will be equal to the revenue collected under an equivalent tariff (in terms of its restrictive effects). ${ }^{82}$ Without such auctions the revenue effect of the quota will accrue to importers, or to exporters, or to both, depending on their relative market power. Problems of measurability aside, the agreement could provide for recompensating such accruals in accordance with a specific formula.

The redistributive effect of a quota has domestic and international aspects: one, a redistribution of income between domestic producers and consumers, the other, a redistribution between groups in different countries (terms of trade effect). Finally, there will be the macro-economic balance of payments and employment effects.

There is one important theoretical advantage in analysing the use of quotas in multilateral agreements as opposed to unilateral imposition: the possibility of retaliation is precluded, at least as long as the agreement stands. This means that the case for international quota type commodity agreements has been made if it can be shown:

(I) that the agreement leads to more certainty in markets where its absence is a major obstacle to optimal resource allocation in response to changing conditions of production and consumption;

${ }^{20}$ MEIER, op. cit. supra note 26 , at $6 \mathrm{r}$.

${ }^{80}$ Kindleberger, op. cit. supra note 27 , at II3.

s1 Their opposite, an agreement on consumption and trade encouraging measures, is also possible. Its economic effects will have to be treated in analogy to the effects of advertising. Problems arise mainly because of the ambiguous nature of "artificially induced" demand and the measurability of its economic contribution.

${ }^{32}$ C. P. Kindleberger, International Economics 245 ff. (3d ed. 1963 ). 
(2) that increased certainty reduces the cost of production and marketing, and that such savings are passed on through the market;

(3) that greater certainty in the specific commodity markets makes national anticyclical policies possible where they would have been ineffective due to lack of control over cyclical disturbances transmitted from abroad;

(4) that the agreements replace existing (or prevent the initiation of new) commercial policies of a more restrictive production and trade reducing nature; ${ }^{33}$ and

(5) that the domestic and international income effects associated with all control agreements are acceptable under both economic and social standards.

s: It must not be assumed that restrictive agreements always represent the interests of exporter countries. The quotas of the International Sugar Agreement of 1959 expressed the interests of highly protective European sugar producers rather than Cuban interests in greater quotas and lower prices. 